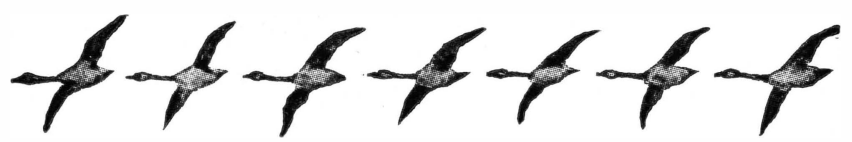

\title{
LIST OF INITIALS AND TAIL-PIECES
}

Page 24 Primrose Falls, Fall Creek, Cornell University Campus.

Page 25 Coy's Glen near Ithaca: upper falls.

Page 59 Lake Temagami, Ontario, Canada.

Page 76 A "carry" between lakes.

Page 77 Buttermilk Creek near Ithaca.

Page $88 \quad$ On the Apalachicola.

Page 89 Pond in the Montezuma Marshes, Central New York.

Page 99 Six Mile Creek near Ithaca.

Page roo A spray of Buttonbush.

Page ${ }_{5} 8$ Water Shamrock and Water Spider.

Page $242 \quad$ Pool at foot of Primrose Falls, Fall Creek.

Page 28I Maligne Lake, British Columbia. (Photo by J. C. Bradley.)

Page 282 Coy's Glen at the mouth.

Page 293 Gorge of Six Mile Creek near Ithaca.

Page 3I4 Williams Brook, near the Cornell U. Biol. Field Station.

Page 315 The Staircase Falls, Coy's Glen.

Page 375 Sunfish swimming. Photo by Dr. R. W. Shufeldt.

Page 377 Duck Creek, near Cincinnati, Ohio.

Page 379 Shocked Cat-tail Flags on the Montezuma Marsh.

Page 40I Lowermost fall of Buttermilk Creek near Ithaca. 